\title{
Ecological Mapping in Application to Aquatic Ecosystems Bioindication: Problems and Methods
}

\author{
*Sophia Barinova \\ Institute of Evolution, University of Haifa, Israel
}

Submission: June 22, 2017; Published: June 29, 2017

*Corresponding author: Sophia Barinova Institute of Evolution, University of Haifa, Mount Carmel, 199 Abba Haifa 3498838, Israel, Tel: +972-48249799; Email: sophia@evo.haifa.ac.il

\begin{abstract}
Paper represented the new mapping methods that involve maximal and adequate variables and indices for ecological assessment of the diverse types of water bodies. Basin approach was implemented for the ecological data collection and mapping. The new approach for the reverie ecosystem mapping is presented in which was mapped data about classification ranks of index saprobitys and nitrate concentration in the water of the sampling stations on the river basin. So, maps revealed not only parts of the river channel but the catchment basin area, which are responsible for the different types of water pollution. Mapping of the ecosystem state index WESI in of a technogenically-impacted reverie basins and water bodies can help for reveal the pollution sources and areas where aquatic ecosystem was impacted. New simply method for the statistically generated mapping in the lentil water bodies surface for diverse variables such as chemical, biological and physical is presented.
\end{abstract}

Keywords: Ecological mapping; Bioindication; Algae; Aquatic ecosystem; Indices; Rivers; Lakes

\section{Introduction}

The bioindication methods are used to reduce the cost of monitoring water bodies. Moreover, bioindicative assessments of water quality and the state of aquatic ecosystems provide more general, integrated results based on the notion of the aquatic ecosystem as a unity of the environment and the biota inhabiting it. Environmental assessments are designed to show not only the existing state of pollution of water bodies, but also to enable the classification of water quality. Environmental assessments are designed to show not only the existing state of pollution of water bodies, but also to enable to classify water quality [1,2] as a basis for environmental and economic decisions. Environmental assessments are designed to show not only the existing state of pollution of water bodies, but also to enable to classify water quality as a basis for environmental and economic decisions $[3,4]$. One of the methods that give an integral representation of the results of bio indication is environmental mapping. However, until recently, the methods used for mapping have been timeconsuming, limited, and difficult to interpret $[3,5]$. We assume that modern approach in combination with statistical methods can improve this important instrument of the bio indication results presentation. The aim of study was to choose the most informative, integrated, detail, simply, and easy usable mapping methods that can be implemented for all available data of environmental and biotic variables in bio indication of aquatic ecosystems.

\section{Method}

Available data in the aquatic ecosystems monitoring are represented by two sets of data:

a. Environmental data that included chemical, physical morph metric and climatically related data, and

b. Biotic data such as algal, invertebrate and aquatic plants species number, abundance and biomass, as well as bioindication groups represented by species number of each, as well as indices calculated for aquatic community and its environment such as Index saprobity, Index Shannon, Index WESI and many other.

Two types of aquatic objects can be mapped in our approach: continental water bodies like rivers and streams, and the lentic water bodies such as lakes and reservoirs. In the both cases, we implemented the basin approach for the maps construction.

The basin approach presupposes a certain system of hydrochemical and hydrobiological data mapping, which was not used before. That is, a station on a watercourse, where water and biota indicators are defined, is considered a characteristic of 
the catchment area that this station has (up to a higher station) and a watercourse within it. Thus, two variants of mapping by stations are accepted:

a. Linear along the watercourse and

b. The catchment area of the catchment basin.

The first mapping option was adopted in the EU countries, the second one is proposed and used by us and allows us to consider, jointly on the area of the basin, loading territorial indicators and indicators of aquatic ecosystems for integrated environmental assessment.

Basin approach in the interpretation of data requires a systemic approach in assessing the state of aquatic ecosystems [1]. Under the "water ecosystem" in this case is understood the unity of the environment and biota. The assessments are carried out according to a certain scheme, depending on the purpose and type of monitoring in order to obtain necessary and sufficient information on the state of the aquatic ecosystem so that its development can be forecasted and directed. The basin approach makes it possible to identify critical areas in the catchment basin. The final product is a series of electronic basin maps. We implemented more statistical methods for the data mapping in the lentic water bodies' ecological assessments like the Statistica 12.0 Program. It help us to construct the area with a gradient of the mapped variable of the aquatic object surface if we have the GIS coordinates of each sampling station. The wafer plots can repeat the water surface area form if the sampling points were a number.

\section{Analysis of bioindication Data in the basin approach}

Basin approach applied at present in different countries $[6,7]$ as the basis for the "GAP-analysis" [8] includes optimization of the work using mapping in GIS.

Spatial organization of the data [6] includes their collection following the scheme that was partly mentioned in [1]:

a. Hydrographic studies on the lake and river basins

b. Latitude mapping

c. Geology of rocks

d. Landscape diversity

e. Vegetation

f. Climate variables

g. Bedrock

h. Hydrological regime

i. Morphometry of lakes and rivers

j. Height of the water body above sea level

k. Dislocation of monitoring station in the basin of the river or lake with GIS coordinates;

1. Structure of the river net of the basin

m. Water velocity

n. Geomorphology of the water body

o. Temperature and hydro chemical regime

In the above-mentioned scheme [6], biological indices are absent. However, the Water Framework Directive recommends partial mapping of the results of biological investigations obtained in different sections of watercourses. In this case, these data should be classified [9]. From our point of view, it is essential to compare the data obtained at the studied station with those registered at the station located upstream of it $[10,11]$. Thus, both hydrochemical and biological data expressed in terms of the indices of contamination can be subjected to the GAP-analysis using GIS. Consequently, contaminated sections, and also the sources of contamination, can be revealed [10-12].

Special color code accepted in the countries of the European Union is used in mapping. In this case, the color of the watercourse (EU method) or its catchment area (our method) can vary from blue to red (Table 1). It depending on the trophic level of the studied section of the river [13], its status in the system of risk assessment $[14,15]$, or classification status in terms of certain element (nitrate and phosphate concentration and other chemical indices), and also on biological data expressed in terms of saprobity indices, etc. [1].

Table 1: Color code of the European Community countries risk assessment with Ecological State and Water Quality Class.

\begin{tabular}{|c|c|c|}
\hline $\begin{array}{c}\text { Class of Water } \\
\text { Quality }\end{array}$ & Ecological State & Color Code \\
\hline I & High & Blue \\
\hline II & Good & Green \\
\hline III & Medium & Yellow \\
\hline IV & Low & Orange \\
\hline V & Bad & Red \\
\hline
\end{tabular}

Consequently, the maps of loads, classification of the state of aquatic ecosystems, and classification of water quality can be compared. Results of ecological mapping are used in risk assessment [13]. Studies that are more detailed are carried out below. The scheme of data collection can be reduced depending on the purpose and/or the type of monitoring. The obtained information on the state of aquatic ecosystem can be used for predicting its development. Based on chemical data and saprobitys indices classification; we constructed ecological maps for each studied river basin or lake. The ecological mapping was proved instrumental in revealing the stations and areas that are problematic for each river or reservoir in respect to their ecosystem stability and self-purification. 


\section{Ecological Mapping Of The Bioindication Results}

The ecological mapping approach was employed to reveal the targets and power of impacts on the fresh water river in and lentic water body's ecosystems. The data for the map is based on the assessments of bioindication and chemical variables. A comparison of the density/diversity indices and distribution of pollutants over the river or Lake Basin monitoring stations, as well as a statistic approach and modeling were used to reveal the risk factors for the studied aquatic ecosystem. Two types of bioindication results, chemical and biological including indices, can be correlated with the real geographic contour of the studied aquatic object:

\section{a. Lakes and other lentic water bodies, and \\ b. Riverine basins}

\section{Lakes and Reservoirs bioindication data mapping}

The first type ecological maps is very required in purpose to compare surface distribution of different variables, especially chemical and biological, but up to now represent of many difficulties in construction with special data mining and programs. Usually the data of variables in the lake type of object coming from different sampling stations represented the lake surface. Therefore, each surface station can be positioned with its geographical coordinates. Table of bioindication results and chemical and other climatic variables therefore can be represented with coordinates of each data. It can be placed on the geographic outlined surface projection if the sampling stations are rather high in number. The first type of ecological map construction is not required any more instrument data avoid Statistica 12.0 program. This modern version of program can help for scientists to construct the ecological maps. The maps, as an example, were constructed for few objects from different climatic regions.

\section{Mapping of the reservoir in arid climatic zone - the Shardara}

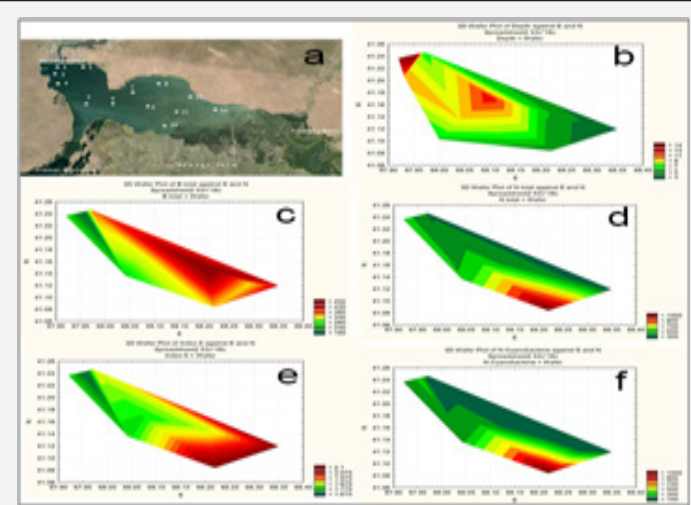

Figure 1: Maps of variables in the Shardara reservoir stations (a), depth (b), total phytoplankton biomass (c) and abundance (d), Index Saprobitys (e), abundance of Cyanobacteria (f).
So, the large manmade aquatic object in the Central Asia arid zone, the Shardara reservoir in Kazakhstan [16] is very important water storage that needs not only water quality assessment but also monitoring of its biological settlements that responsible to the self-purification process. The Shardara reservoir (Kazakhstan) mapped variables show (Figure 1) that water depth is increased in the lake center as well as near the Karakum canal output. Total phytoplankton biomass is increased near the wastewater from the agriculture farms and the Amudarya river input (Figure 1), and controlled by cyanobacteria. The Syrdarya and Amudarya rivers input that have organically enriched water are indicate total biomass and Index saprobitys. Therefore, our mapping gives not only contamination sources but also show the response of the lake ecosystem to its impact.

\section{Mapping of a lake with a complex surface configuration - the Balkhash Lake}

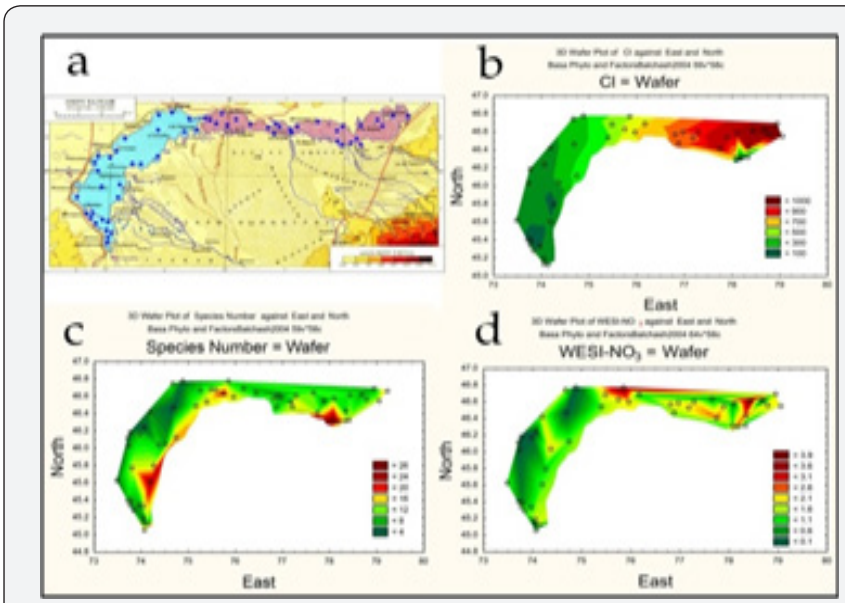

Figure 2: The Balkhash Lake map of the complex configuration of the Lake Surface and sampling points (blue) (a), gradient of salinity wafer map (b), phytoplankton species number wafer map (c), and ecological risk assessment with index WESI wafer map (d).

The Balkhash Lake is a unique natural object with a gradient of the total content of dissolved salts along its longitudinal axis (Figure 2). The increased level of toxic pollution of the lake is related both to its location in the zone of ore deposits and to the economic activity within its watershed. Phytoplankton has been used to assess the ecological state of the Balkhash Lake with Chlorophyta prevalence in the western, fresher water part, and Bacillariophyta in the eastern, brackish part from a total 92 species [17]. Mapping showed a positive relationship between the species richness of plankton algae and macrophytes and negative correlation with the chlorides concentration in the lake water (Figure 2). Changes in the proportion of indicator species within the composition of phytoplankton reflected the spatial gradient of environmental parameters - an increase in depth, TDS (Total Dissolved Solids), pH-values, trophic level and organic pollution in the direction from west to east. The water of the Balkhash Lake was moderately polluted, Class III of water quality according to bioindication data. 
The WESI index calculation revealed the effect of the total toxic pollution on the phytoplankton of the Western Balkhash (Figure 2). Despite the differences in the salt composition of water and the level of organic and toxic pollution, bioindication illustrated the unity of the species composition of phytoplankton in the Western and Eastern Balkhash. In conclusion, the method of statistical mapping of indicators in combination with bioindication based on algae can be successfully used to monitor changes in water quality and identify sources of pollution of the unique natural object - the Balkhash Lake.

\section{Techno-ecosystems bioindication data mapping}

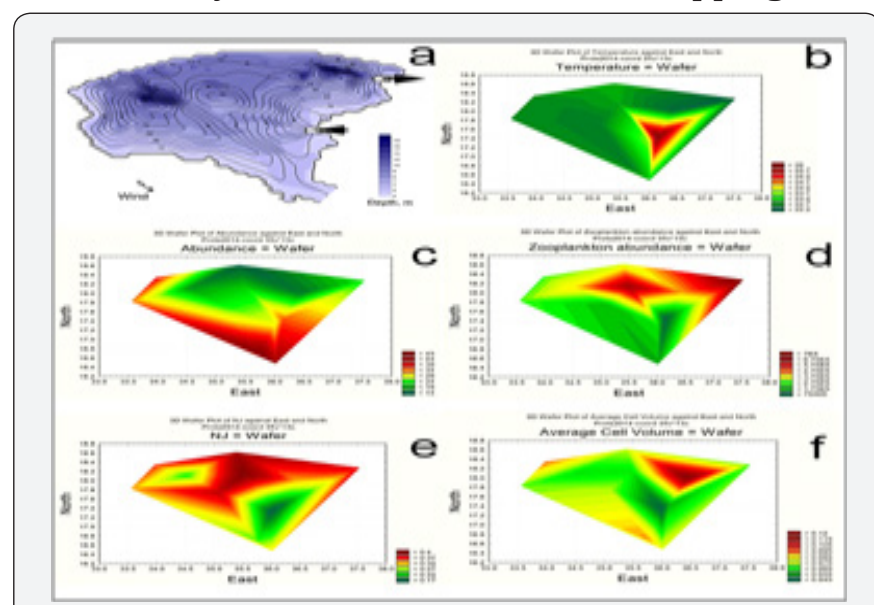

Figure 3: Maps of variables in the Khmelnitsky NPP stations (a), water temperature (b), total phytoplankton (c) and zooplankton (d) abundance, Index Shannon (e), and average phytoplankton cell volume (f).

The cooling pool at the Khmelnitsky NPP (KhNPP), Ukraine is the reservoir [18] that was constructed for the power station input water cooling (Figure 3a) with maximal depth about 20 $\mathrm{m}$. Mapped temperature (Figure $3 \mathrm{~b}$ ) pointed on the station that placed near hot water input the temperature of which is rapidly decreased. The phytoplankton and zooplankton abundance are correlated negative (Figure 3c,d). The average cell volume in phytoplankton is maximal in the stations that placed near water output (Figure 3f) and where the zooplankton abundance increased (Figure 3d). In the same stations the Shannon Index of the aquatic community structure complicity is maximal (Figure 3e). Therefore, the ecological maps help to conclude that zooplankton have positive impact to the cooling pool ecosystem of the Khmelnitsky NPP.

\section{Mapping of a estuarine reservoir - the Sasyk}

The Sasyk reservoir (Ukraine) has a long story from the Black Sea estuary to manmade reservoir in purpose of fresh water store [19]. The reservoir is shallow, up to $3 \mathrm{~m}$ deep with high homogeneity of the water and phytoplankton variables. Assessment of its ecosystem with help of constructed in first ecological maps[20] in the Statistica 12.0 program (Figure 4) on the base of bio indicators in phytoplankton give us to conclude that water temperature have not heterogeneity and increased in shallow coastal zone (Figure 4b). Averaged cell volume of phytoplankton and Index Shannon were correlated (Figure 4c,d) and show that ecosystem in the peripheral part of the reservoir is most stable. Indicators of high $\mathrm{pH}$ water are represented mostly in upper part of reservoir in the Kogylnik River input (Figure 4e). Indicators of salinity show impact of sea waters in the south-western part near the dam (Figure 4f). These results can be revealed on the base of species-indicators distribution on the reservoir surface with help of ecological maps only.

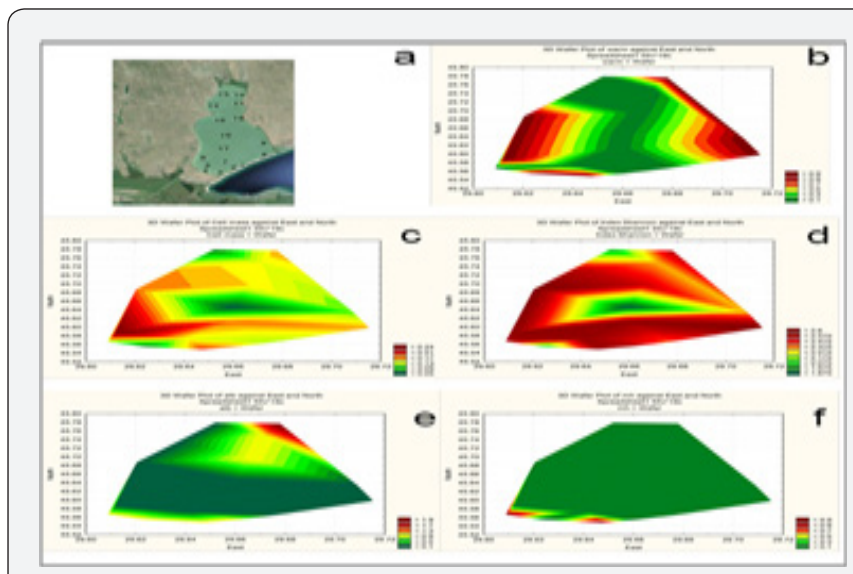

Figure 4: Maps of variables in the Sasyk reservoir stations (a), warm-water temperature indicators (b) average phytoplankton cell mass (c), Index Shannon for the phytoplankton communities (d) alkalibiontes indicators (e), mesohalobes indicators (f).

\section{Rivers and streams bioindication data mapping}

The results of the reverie bioindication can be represented on the real map of the catchment basin of studied aquatic object or its part. Our approach to the ecological map construction included not only the mapping of the river channel water quality, as practice is in the EC country [9], but also highlighting the catchment areas not only as a whole [21] but also that affect each of the monitoring stations. At a result of the map analysis, we distinguish not only the problematic points on the river channel, but also the objects that cause a disturbance of riverine communities. Therefore, the mapping process includes two stages:

a. Construction of map of the nitrate concentration rank and

b. Construction of the saprobitys indices rank map.

Their comparison provides for location of pollution source in the catchments area.

\section{Small river basin mapping - the Upper Jordan River}

Ecological mapping of this type was done in the first time in Israel for the Upper Jordan River basin and later for the coastal rivers Qishon, Hadera, Alexander and Yarqon. Ecological maps (Figures 5) constructed for the Upper Jordan River appear different for the wet and dry seasonal communities $[11,12]$. Whereas the Index S map shows good or moderate water quality, 
the nitrate map reflects poor water quality in the Upper Jordan River in winter at most monitored stations. The summer maps show a much better situation in respect of saprobitys level as well as nitrate concentration.

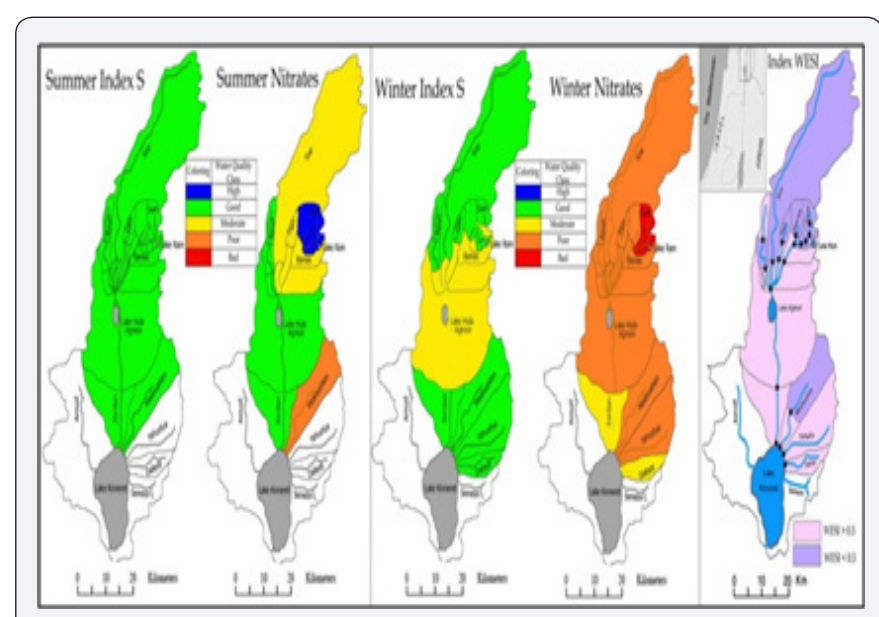

Figure 5: Ecological maps of the Upper Jordan River Basin constructed based on full screening analysis for the saprobitys index $S$ and nitrate concentrations in 20062009 monitoring with the Index WESI calculation mapping

Therefore, the Upper Jordan River was mostly polluted in winter. However, the preliminary mapping analysis does not help us in locating the point sources and areas of pollution in the basin. Because of this, we had to perform a detailed monitoring in the winter season of 2009. As can be seen in Figure 5, the self-purification capacity was high in the upper tributaries, lower reaches and the Meshushim River in the upper part of it placed many agricultural and livestock farms. Nevertheless, the river waters were considerably enriched in nitrates in the Saar tributary stations near Mount Hermon. The Saar can be marked out as a pollution source for the Upper Jordan River in winter. This result, obtainable with ecological mapping analysis alone, is significant for the Make Decision System, because the Upper Jordan River is a major drinking water source in Israel.

\section{Mapping of a large scale reverie basins}

Next example of ecological mapping of algal bioindication results is represent by low-resolution maps of the Eastern Europe, Russia. Many years ago, we outlined the major reverie basins (Figure 6) in the CIS - Former Soviet Union territory [10] but the material come for European part of the rivers only. Figure 7 show imbalance in the water quality assessment for the environmental (nutrients concentration) and biological (Index saprobity S) variables. Comparison of both maps represents higher ranks in nutrients and lower rank in Index S in the same river basin. It can be interpreted as impact on the biological part of the river ecosystem and stress of photosynthetic activity of the first trophic level - the algae.

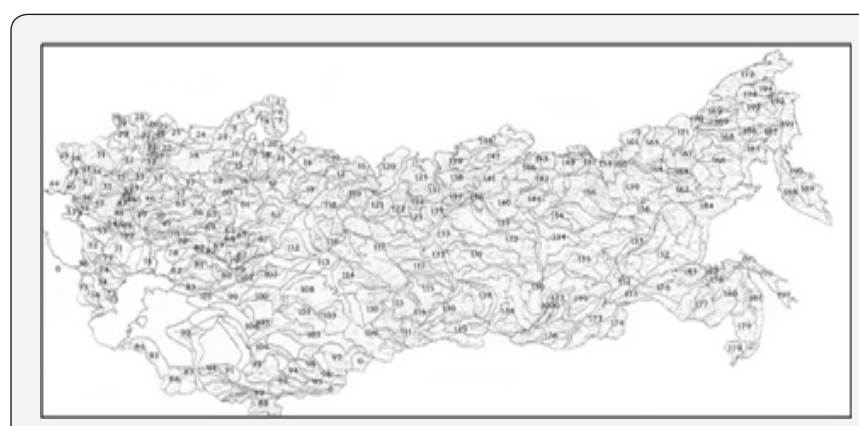

Figure 6: Map of small rivers catchment basins in Russia and Commonwealth of Independent States (formerly the USSR).

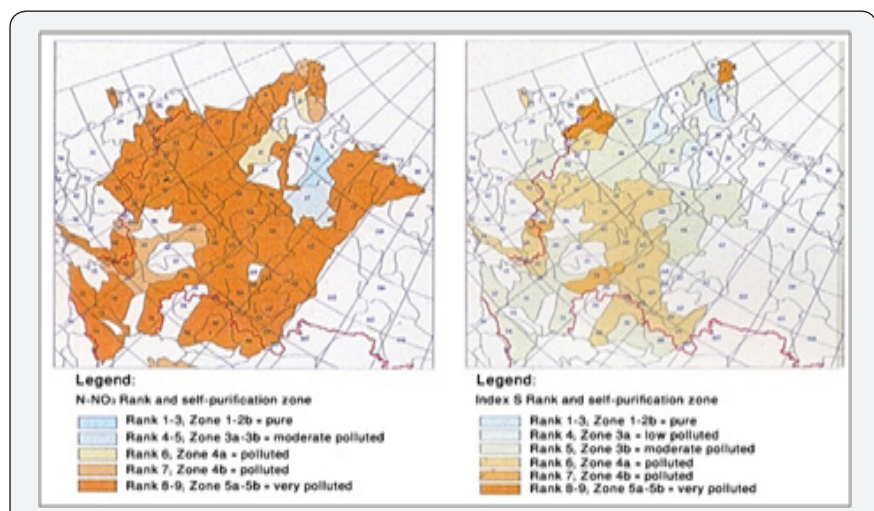

Figure 7: Environmental risk assessment maps of small rivers of European Russia. Left - Map of nutrients concentration in the water; Right - state of the first trophic level of aquatic ecosystems assessed with the Index of saprobitys S. Ranks of water quality and self-purification zones are as in [1].

\section{Mapping of a technogenically-impacted reverie basin - the Pronya River}

An example of an integrated basin assessment involves gathering as much information as possible according to the scheme [1], as was done for the analysis of the ecological situation in the basin of the Pronya River (Figure 8) where placed the Ryazan Power Station. It is the fifth largest oil-fired power station in the world, also the fifth largest power station in Russia, with an installed capacity of 3,130 MW. The power station is located in Novomichurinsk of the Ryazan Oblast, Russia [22]. Concentration of metals in water and bottom sediments, heavy organic matter in water, algal biodiversity, fish, loads of trophic elements and xenobiotics, distribution of discharges and discharges through the basin were made, bioindication and biotesting were carried out.

The key link was the results of the analysis of the state of aquatic ecosystems and their basin mapping (Figure 8), where a correlation was found between the concentration of heavy metals and toxic effects on ecosystems with emission fields of pipes at the Ryazan PS. On the (Figure 8) can be seen our assessment map of the Index saprobity data (c) and the nitrates concentration in the river water (d). The comparison of both maps give the areas 
that responsible for the water quality from an ecological point of view. But, most informative map is for the Index WESI (b) where can be seen the concentric areas with emission impact that coincident with the measured wind directions served as a basis for building a wind rose [23], left below on the figures. Interesting that the clean water areas were on the periphery of the Pronya River basin (blue) as well as under the two reinforced concrete chimneys with height of 320 meters that are among the ultra-high buildings, each of them is a 28-nd height chimney in the world.

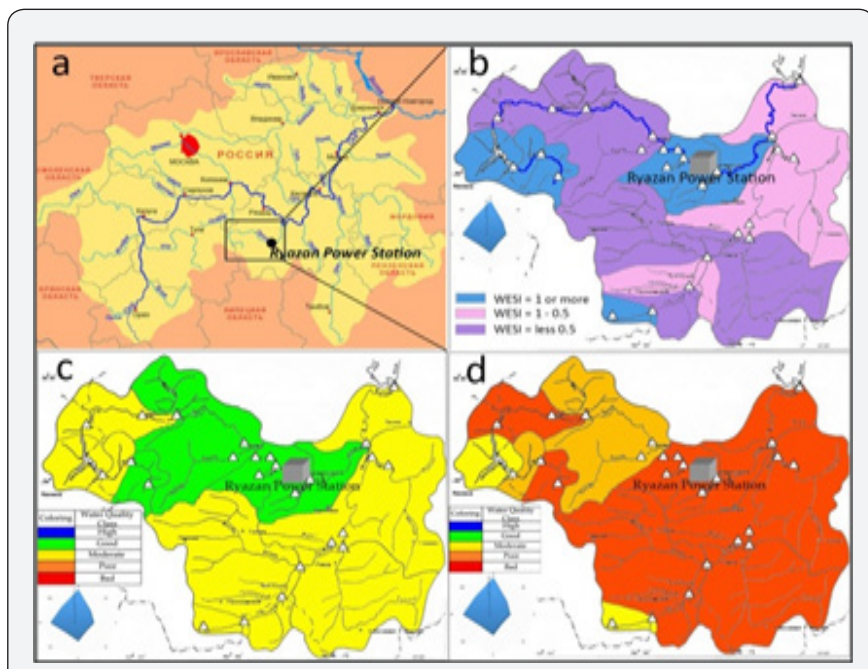

Figure 8: Environmental risk assessment maps on the Pronya River basin, European Russia. Basin the Oka River with the Pronya River tributary position, blue (a). WESI map with the Pronya River tributary position (blue) and the wind rose (b). Index saprobitys $S$ map under EU color code of water quality (c). Nitrates concentration in the . Ranks River waters under EU color code of water quality (d). Ranks of water quality and self-purification zones are as in [1].

Two metal chimneys have a height of 180 meters [22]. Both highest chimneys and two other are responsible to emission of Coal, Fuel oil, and Natural gas fuel combustion products. As well known the most enriched by heavy metals is the fuel oil. So, the chimneys are so high so under them the emission precipitation is not impacted of ecosystems. As a result of our mapping, we can not only top assess the water and biotic sustainable in the river basin but also to find the cause of the reverie ecosystem toxic impact, such as emission of fuel oil combustion products.

\section{Conclusion}

In purpose of pollution impact assessment on the fresh and brackish water ecosystems were implemented the mapping approach of the bioindication results that presented major groups of biotic and environmental indicators maps [11]. Calculation of the saprobity indices $S$ that are wide used in the monitoring systems of EU countries was included in the mapping to betrays the spatial dynamics and seasonal fluctuations of pollution over the monitoring stations of the studied rivers and lakes. In particular, on account of $\mathrm{S}$ dynamics and ecological mapping, we concluded that while the Upper Jordan River that flows into the Lake Kenner, the main source of drinking water in Israel, was mostly polluted in winter, the coastal rivers were more heavily impacted in summer. This is because the sources of anthropogenic influence on the Upper Jordan River were located in the basin catchments, whereas pollution of the coastal rivers can be related not only to anthropogenic impact on the basin catchments, but also to accumulation of pollutants in the alluvial sediments and their diffusion in summer. But in the both types of rivers the water pollution decreased toward the mouth owing to the self-purification processes as we revealed on the experimental works [24-26].

The ecological mapping based on nutrient concentrations and algal bioindication locates the pollution sources over the basin catchments. The maps reveal seasonality of impacts causing problems for river or lake ecosystems. This approach gave us a detailed picture of the different aquatic objects pollution patterns, pointing to the season or basin area that responsible to the pollution impact. So, including the ecosystem state index WESI in the ecological mapping of a technogenically-impacted reverie basin of the Pronya River in the central European part of Russia help us to reveal concentric distribution of the emission impact to the river ecosystem. Only mapping of WESI show that area under high (320 m) chimneys of the Ryazan Power Station avoid the impact such as in the basin periphery area.

Very productive for the ecological conclusions were the new approach for the statistically generated mapping in the lentic water bodies surface for diverse variables such as chemical, biological and physical. The mapping results can be used not only for the ecological conclusions but also for revealing the important regulating factors on the lake and reservoir ecosystems. Thus, a complex study of algal communities, including the ecological mapping and bioindication assessment of self-purification activity rate, gives important information on the lake or river pollution and ecosystem self-purification capacity that can be used as a basis for the river monitoring and make decision system for the aquatic objects management, conservation and reserve.

\section{Acknowledgement}

This work has been partly supported by the Israeli Ministry of Absorption.

\section{References}

1. Barinova S (2017) On the Classification of Water Quality from an Ecological Point of View. International Journal of Environmental Sciences \& Natural Resources 2(2): 1-8.

2. Barinova SS, Klochenko PD, Belous YeP (2015) Algae as Indicators of the Ecological State of Water Bodies: Methods and Prospects. Hydrobiological Journal 51(6): 3-21.

3. http://www.eea.europa.eu/data-and-maps/explore-interactivemaps/phytobenthos-in-rivers. 
4. https://www.eea.europa.eu/highlights/towards-better-tools-fordecision.

5. Firoz A, Laxmi G, Abdul Q (2017) Natural Resource Mapping Using Landsat and Lidar towards Identifying Digital Elevation, Digital Surface and Canopy Height Models. Int J Environ Sci Nat Res 2(1): 555580.

6. Higgins JV, Bryer MT, Khoury ML, FitzHugh TW (2005) A Freshwater classification approach for biodiversity conservation planning. Conservation Biology 19(2): 432-445.

7. Schiller D, von Acua V, \& Sabater S (2014) Streams: perennial and seasonal. In: Y Wang, Ed, Encyclopedia of Natural Resources: water pp. 853-857.

8. FitzHugh, TW (2005) GIS tools for freshwater biodiversity conservation planning. Transactions in GIS 9(2): 247-263.

9. European Parliament (2000) Directive of the European Parliament and of the Council establishing a framework for community action in the field of water policy. OJL 327: 1-72.

10. Barinova SS, Medvedeva LA, Anissimova OV (2006) Diversity of algal indicators in environmental assessment. Tel Aviv: Pilies Studio, Russia.

11. Barinova S, Krassilov VA (2012) Algal diversity and bio-indication of water resources in Israel. International Journal of Environment and Resource 1(2): 62-72.

12. Barinova SS, Nevo E (2010) The Upper Jordan River algal communities are evidence of long-term climatic and anthropogenic impacts. J Water Resource and Protection 2(6): 507-526.

13. Common implementation strategy for the Water Framework Directive (2003) Guidance document 7 Monitoring under the Water Framework Directive. Luxembourg: European Communities, Europe, pp. 153.

14. Detenbeck NE, Batterman SL, Brady VI (2000) A test of watershed classification systems for ecological risk assessment. Environ. Toxicol. Chemistry 19: 1174-1181.

15. UNEP/IPCS (2006) Training Module No 3, Section C. Ecological Risk
Assessment. Prepared by The Edinburgh Centre for Toxicology.

16. Barinova S, Krupa E (2017) Bioindication of Ecological State and Water Quality by Phytoplankton in the Shardara Reservoir, Kazakhstan. Environment and Ecology Research 5(2): 73-92.

17. Barinova SS, Krupa EG, Tsoy VN, Ponamareva LP (2017) The application of phytoplankton in ecological assessment of the Balkhash Lake Kazakhstan.

18. Protasov AA (2011) Techno-ecosystem of NPP. Hydrobiology, environment, and ecological assessment. Kiev: Institute of Hydrobiology NASU in Russia

19. Bilous OP, Barinova SS, Ivanova (2016) The use of phytoplankton as an indicator of internal hydrodynamics of a large seaside reservoir-case of the Sasyk Reservoir, Ukraine. Ecohydrol. Hydrobiol 160-174.

20. Barinova S, Bilous O, Ivanova N (2016) New Statistical Approach to Spatial Analysis of Ecosystem of the Sasyk Reservoir, Ukraine. International Journal of Ecotoxicology and Ecobiology, 1(3): 118-126.

21. http://water.jrc.ec.europa.eu/waterportal.

22. https://ru.wikipedia.org/

23. https://dwg.ru/dnl/11927. Available 07.05.2017.

24. Tavassi, M., Barinova, S.S., Nevo, E. (2008) Examination of water quality from the Yarqon River (central Israel) using the glass slide method to define algal vegetative activity (in vitro). Applied Ecology and Environmental Research, 6(3):113-125.

25. Barinova S. (2011) Algal diversity dynamics, ecological assessment, and monitoring in the river ecosystems of the eastern Mediterranean. Nova Science Publishers, New York, USA, 363 pp.

26. Lipkovsky, E., Barinova, S., Teltsch, B., Nevo, E. (2011) Algal vegetative activity in the Upper Jordan River (Northern Israel): an in vitro glass slide experiment. Applied Ecology and Environmental Research, 9(3): 231-244.

\section{Your next submission with Juniper Publishers will reach you the below assets}

- Quality Editorial service

- Swift Peer Review

- Reprints availability

- E-prints Service

- Manuscript Podcast for convenient understanding

- Global attainment for your research

- Manuscript accessibility in different formats

( Pdf, E-pub, Full Text, Audio)

- Unceasing customer service

Track the below URL for one-step submission

https://juniperpublishers.com/online-submission.php 